Jpn. J. Oral Biol., $39:$ 72-75, 1997.

SHORT COMMUNICATION

\title{
Isolation and partial characterization of neuraminidase of Treponema denticola strain $\mathrm{TN}-2$
}

\author{
Kaname Hirai, Syosyu Hoshino, Yukinaga Shibata, Setsuo Fujimura and Takeshi Nakamura
}

Department of Oral Microbiology, Matsumoto Dental College

(Chief : Prof. Takeshi Nakamura)

Hirooka-Gobara 1780, Shiojiri, Nagano 399-07, Japan

(Received on September 13, 1996 ; Accepted on December 2, 1996)

Key words : $T$. denticola / spirochete/neuraminidase/enzyme/purification

\section{Introduction}

Neuraminidase (EC. 3.2.1.18) cleaves $\alpha$-ketosidic linkages between $\mathrm{N}$-acetylneuraminic acid and remaining carbohydrate chains of oligosaccharides, glycolipids and glycoproteins in body fluids, membrane structures and cell surfaces ${ }^{1}$. The enzyme is considered to enhance bacterial adhesion to cells ${ }^{2,3)}$, indicating that neuraminidase plays a role in the early stage of infection. Accordingly, due to our interest in the production and properties of this enzyme of oral indigenous bacteria, We purified and characterized the neuraminidase of Propionibacterium acnes. Microbial neuraminidase has been isolated also from Vibrio cholerae $^{5)}$, Clostridium perfringens ${ }^{6,7)}$, the influenza virus ${ }^{8)}$, and Actinomyces pyogenes ${ }^{9}$.

The spirochetes including Treponema denticola and other treponemes may be the etiological agents of periodontal disease $\mathrm{e}^{10 \sim 14)}$, as treponemes are detected frequently in the inflamed pockets of periodontitis patients ${ }^{13)}$ and in the gingival soft tissues of patients with acute necrotic ulcerative gingivitis and in advanced periodontitis lesions ${ }^{15}$.

Conceivable invading enzymes of $T$. denticola, such as the trypsin-like enzyme ${ }^{16)}$, chymotrypsin-like enzyme $^{17)}$, and elastase-like enzyme ${ }^{18)}$, have been isolated and characterized. Recently, we found that a strain of $T$. denticola elaborated the trypsin-like enzyme, chymotrypsin-like enzyme, and collagenase. These proteolytic enzymes were separated by column chromatography ${ }^{19}$. Simultaneously, we detected production of neuraminidase of the same strain. In the present report the isolation and partial characterization of this enzyme of $T$. denticola are described.

\section{Materials and Methods}

\section{Bacterial strain and culture conditions}

T. denticola strain $\mathrm{TN}-2$ was isolated from the lesion of an adult periodontitis patient in our laboratory ${ }^{19}$. Organisms were grown in an anaerobic glove-box filled with a mixture of gases $\left(85 \% \mathrm{~N}_{2}, 10 \%\right.$ $\mathrm{H}_{2}, 5 \% \mathrm{CO}_{2}$ ) at $37^{\circ} \mathrm{C}$ for five days in the medium described by Ohta et $a l^{16)}$.

\section{Assays}

Neuraminidase activity was measured using 2'-4methylumbelliferyl- $\alpha-\mathrm{D}-\mathrm{N}$-acetylneuraminic acid (MUA, Sigma Chem. Co. St. Louis, M. O. USA.) as a substrate according to the method of Potier et al. ${ }^{20)}$ Briefly, the reaction mixture contained $0.3 \mathrm{mM}$ MUA,

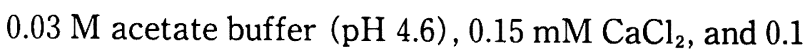
$\mathrm{m} l$ of enzyme solution in a total volume of $0.6 \mathrm{~m} l$. The mixture was incubated at $37^{\circ} \mathrm{C}$ for $30 \mathrm{~min}$, and the reaction was stopped by the addition of $2 \mathrm{ml}$ of 0.133 $\mathrm{M}$ glycine buffer ( $\mathrm{pH} 10.7$ ) containing $0.06 \mathrm{M} \mathrm{NaCl}$ and $0.083 \mathrm{M} \mathrm{Na}_{2} \mathrm{CO}_{3}$. The amounts of free 4-metylum- 
belliferone liberated from MUA were determined by spectrofluormeter, type 650-10 (Hitachi, Tokyo) using excitation light at $365 \mathrm{~nm}$ and fluorescence emission at $450 \mathrm{~nm}$. One unit of neuraminidase was defined as the amount of enzyme which liberated one nmol of 4-methylumbelliferone per min.

Protein was determined by the method of Bradford $^{21)}$ using a protein assay system (Bio-Rad Laboratories, Richmond C.A. USA.) with bovine serum albumin (Sigma Chem. Co.) as standard protein.

\section{Purification of neuraminidase}

All purification procedures described below were carried out at $4^{\circ} \mathrm{C}$. $T$. denticola cells were removed by centrifugation at $12,000 \times \mathrm{g}$ for $20 \mathrm{~min}$, and ammonium sulfate was added to the culture supernatant to make a final concentration of $80 \%$ saturation. The resultant precipitate was collected by centrifugation at $12,000 \times$ $\mathrm{g}$ for $20 \mathrm{~min}$ and dissolved in $0.05 \mathrm{M}$ Tris- $\mathrm{HCl}$ buffer (pH 7.2), and dialyzed against the same buffer overnight. The dialyzed material was applied to a column (2.6 by $38 \mathrm{~cm}$ ) of Q-Sepharose Fast Flow (Pharmacia Biotech. Inc. Uppsala, Sweden) equilibrated with 0. $05 \mathrm{M}$ Tris- $\mathrm{HCl}$ buffer ( $\mathrm{pH}$ 7.2). After the column was washed with the buffer, the enzyme was eluted with a linear $\mathrm{NaCl}$ gradient from 0 to $0.5 \mathrm{M}$ in the same buffer. The fraction with the enzyme activity was pooled and dialyzed against $0.05 \mathrm{M}$ Tris- $\mathrm{HCl}$ buffer ( $\mathrm{pH}$ 7.2), followed by concentration using a rotary evaporator in vacuo. The concentrated neuraminidase fraction was further purified by gel filtration on Sephacryl S-300 (Pharmacia Biotech. Inc.) (2.4 by 90 $\mathrm{cm}$ ), equilibrated with $0.05 \mathrm{M}$ Tris- $\mathrm{HCl}$ buffer $(\mathrm{pH} 7$. 2) containing $0.15 \mathrm{M} \mathrm{NaCl}$, and the column was eluted with this buffered saline at a flow rate of $20 \mathrm{ml} / \mathrm{h}$.

\section{Estimation of molecular weight}

The molecular weight of the enzyme was estimated by sodium dodecyl sulfate $10 \%$ polyacrylamide gel electrophoresis (SDS-PAGE) ${ }^{22}$. The gels were stained with silver.

\section{Effects of metal ions and ethylenediamine-} tetraacetic acid (EDTA)

Effect of $\mathrm{Ca}^{2+}, \mathrm{Mg}^{2+}, \mathrm{Fe}^{2+}, \mathrm{Co}^{2+}, \mathrm{Mn}^{2+}, \mathrm{Zn}^{2+}, \mathrm{Cu}^{2+}$ or EDTA on neuraminidase activity was examined at 1 $\mathrm{mM}$ of each agent. Activity was expressed as the percentage of the value for the control experiment, which did not include the test agents.

\section{Effect of $\mathbf{p H}$}

Enzymatic activity at different $\mathrm{pH}$ levels was compared using acetate buffer ( $\mathrm{pH} 4.0$ to 7.0 ), Tris -maleate buffer ( $\mathrm{pH} 7.0$ to 7.5), and Tris- $\mathrm{HCl}$ buffer (pH 7.5 to 9.0), each at a final concentration of $0.15 \mathrm{M}$.

\section{Results and Discussion}

Neuraminidase was purified from the culture supernatant of $T$. denticola $\mathrm{TN}-2$ by column chromatography and gel filtration. The purity of the enzyme increased 276 -fold with a recovery of $30 \%$ (Table 1 ). The molecular weight was calculated as being $50 \mathrm{kDa}$ (Fig. 1).

The effects of divalent ions and EDTA on neuraminidase activity is summarized in Table 2. Of the metal ions tested, $\mathrm{Ca}^{2+}$ markedly stimulated the activity. However, $\mathrm{Mg}^{2+}$ exhibited an inhibitory effect. About half the activity was inhibited by $\mathrm{Fe}^{2+}, \mathrm{Co}^{2+}$, or $\mathrm{Mn}^{2+}$. Partial inhibition and complete inhibition were caused by $\mathrm{Zn}^{2+}$ and $\mathrm{Hg}^{2+}$ or $\mathrm{Cu}^{2+}$, respectively. Substantial inhibition was observed by a chelator, EDTA.

Activity was considerably influenced by different $\mathrm{pH}$ values of the reaction mixtures (Fig. 2), and reached maximum level at $\mathrm{pH}$ 6.5. Activation by $\mathrm{Ca}^{2+}$ and slight inhibition by EDTA of the $T$. denticola $\mathrm{TN}-2$ neuraminidase were also observed by the same enzyme isolated from an oral strain of Propionibacter. ium acnes ${ }^{4}$. However, the enzyme from these microorganisms may be distinct from each other, since significantly different properties in molecular weights and optimum $\mathrm{pH}$ levels for the reaction were found.

The in vivo function of neuraminidase of $T$. denticola remains obscure, however, the activities of neuraminidase and the neuraminidase-related enzyme, considered to originate from oral bacteria, in the human crevicular fluid from patients with per. 
Table 1 Purification of neuraminidase of Treponema denticola TN-2

\begin{tabular}{lccccc}
\hline \multicolumn{1}{c}{ Step } & $\begin{array}{c}\text { Total } \\
\text { protein } \\
(\mathrm{mg})\end{array}$ & $\begin{array}{c}\text { Total } \\
\text { activity } \\
(\mathrm{U})\end{array}$ & $\begin{array}{c}\text { Specific } \\
\text { activity } \\
(\mathrm{U} / \mathrm{mg})\end{array}$ & $\begin{array}{c}\text { Purification } \\
\text { (fold) }\end{array}$ & $\begin{array}{c}\text { Yield } \\
(\%)\end{array}$ \\
\hline Culture supernatant & 2,435 & 62,470 & 26 & 1 & 100 \\
Ammonium sulfate & 862 & 45,084 & 52 & 2 & 72 \\
Q-Sepharose Fast Flow & 84 & 31,600 & 376 & 14 & 51 \\
Sephacryl S-300 & 2.6 & 18,650 & 7173 & 276 & 30 \\
\hline
\end{tabular}

A $\quad$ B

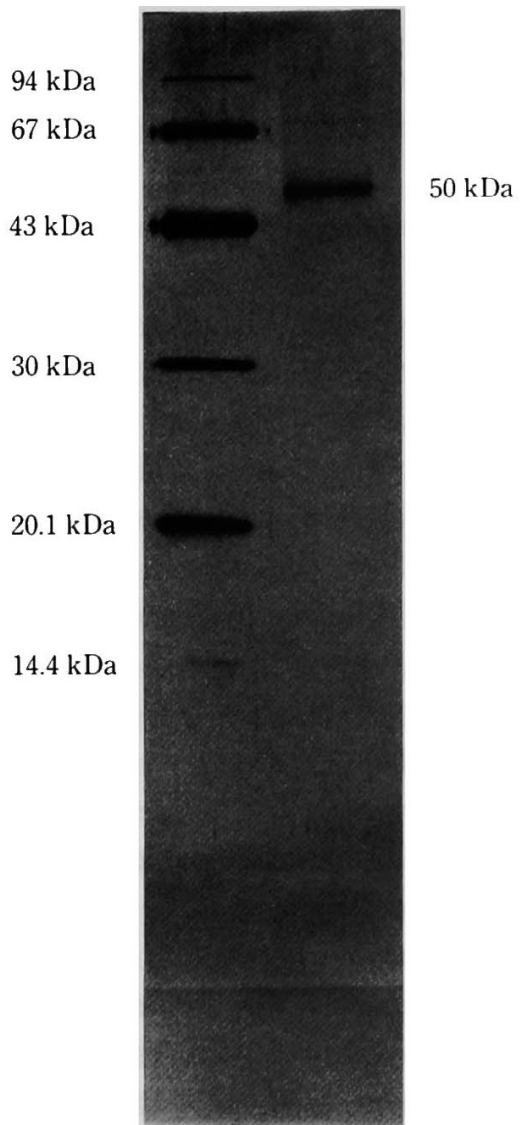

Fig. 1 SDS-PAGE of the purified neuraminidase.

Lane A : standard proteins. Values indicate molecular masses $(\mathrm{kDa})$.

Lane B : the purified neuraminidase from Sephacryl S300 .

iodontitis was substantially higher than that of healthy subjects ${ }^{23,24)}$. These observations suggest that neuraminidase from oral microbial residents may be implicated, if not directly, in the onset and/or development of periodontitis.
Table 2 Effect of divalent ions or EDTA on the neuraminidase activity

\begin{tabular}{lcc}
\hline & $\begin{array}{c}\text { Concentration } \\
(\mathrm{mM})\end{array}$ & $\begin{array}{c}\text { Relative activity } \\
(\%)\end{array}$ \\
\hline None & - & 100 \\
$\mathrm{Ca}^{2+}$ & 1.0 & 268 \\
$\mathrm{Mg}^{2+}$ & 1.0 & 64 \\
$\mathrm{Fe}^{2+}$ & 1.0 & 49 \\
$\mathrm{Co}^{2+}$ & 1.0 & 50 \\
$\mathrm{Mn}^{2+}$ & 1.0 & 49 \\
$\mathrm{Zn}^{2+}$ & 1.0 & 27 \\
$\mathrm{Hg}^{2+}$ & 1.0 & 0 \\
$\mathrm{Cu}^{2+}$ & 1.0 & 0 \\
EDTA & 1.0 & 43 \\
\hline
\end{tabular}

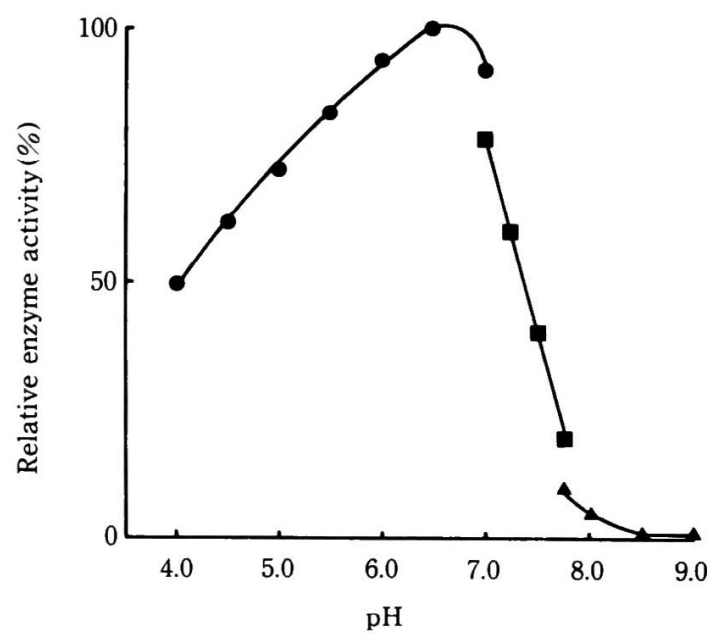

Fig. 2 Relationship between $\mathrm{pH}$ and the enzyme activity. ; acetate buffer, $\mathbf{\square}$; Tris-maleate buffer,

$\Delta$ : Tris-HCI buffer.

\section{References}

1) Drzeniek, R. : Viral and bacterial neuraminidases. Curr. Top. Microbial. Immunol. 59: 
35 74, 1972.

2) Childs III, W. C. and Gibbons, R. J. : Use of Percol density gradients for studying the attachment of bacteria to oral epithelial cells. J. Dent. Res. 67 : 826 830, 1988.

3) Okuda, K., Ono, M. and Kato, T. : Neuraminidaseenhanced attachment of Bacteroides intermedius to human erythrocytes and buccal epithelial cells. Infect. Immun. 57 : 1635 1637, 1989.

4) Shimura, R., Shibata, Y., Fujimura, S. and Nakamura, T. : Purification and characterization of neuraminidase from oral Propionibacterium acnes. Matsumoto Shigaku 16:276 284, 1990. (in Japanese)

5) Ada, G. L., French, E. L. and Lind, P. E. : Purification and properties of neuraminidase from Vibrio cholerae. J. gen. Microbiol. $24: 409 \sim 421,1961$.

6) Bouwstra, J., B. Deyl, C. M. and Vliegenthart, J. F.G.: Purification and kinetic properties of sialidase from Clostridium perfringens. Biol. Chem. Hoppe-Seyler $368:$ 269 275, 1987.

7) Chien, C.-H., Chang, S.-C. and Wei, Y.-H. : Purification and characterization of neuraminidase from Clostridium perfringens. Proc. Natl. Sci. Counc. B. ROC. $13: 201 \sim 209,1989$.

8) Bucher, D. J. : Purification of neuraminidase from influenza viruses by affinity chromatography. Biochim. Biophys. Acta. 482 : 393 399, 1977.

9) Schaufuss, P. and Lämmler, C. : Characterization of extracellular neuraminidase produced by Actinomyces pyogenes. Zbl. Bakt. 271:28 35, 1989.

10) Armitage, G. C., Dickinson, W. R., Jenderseck, R. S., Levine, S. M. and Chambers, D. W. : Relationship between the percentage of subgingival spirochetes and the severity of periodontal disease. J. Periodontol. 53: 550 556, 1982.

11) Listgarten, M. A. and Levin, S. : Positive correlation between the proportions of subgingival spirochetes and motile bacteria and susceptibility of human subjects to periodontal deterioration. J. Clin. Periodontol. $8: 122 \sim 138,1981$.

12) Loesche, W. J. and Laughon, B. E. : Role of spirochetes in periodontal disease. In : Host-parasite interactions in periodontal disease. (Genco, R. J. and Mergenhagen, S. E., ed.), pp. 62 75, Amer ican Society for Microbiology, Washington DC, 1982.
13) Loeshe, W. J., Syed, S. A., Schmidt, E. and Morrison, E. C.: Bacterial profiles of subgingival plaques in periodontitis. J. Periodontol. 56: 447 $\sim 456,1985$.

14) Olsen, I. : Attachment of Treponema denticola to cultured human epithelial cells. Scand. J. Dent. Res. $92: 55 \sim 63,1984$.

15) Loesche, W. J. : The role of spirochetes in periodontal disease. Adv. Dent. Res. 2:275 283, 1988.

16) Ohta, K., Mäkinen, K. K. and Loesche, W. J. : Purification and characterization of an enzyme produced by Treponema denticola capable of hydrolyzing synthetic trypsin substrates. Infect. Immun. 53:213 220, 1986.

17) Uitto, V.-J., Grenier, D., Chan, E.C.S. and McBride, B. C. : Isolation of a chymotrypsinlike enzyme from Treponema denticola. Infect. Immun. 56:2717 2722, 1988.

18) Mikx, F. H. M., Jacobs, F. and Satumalay, C. : Cell-bound peptidase activities of Treponema denticola ATCC 33520 in continuous culture. J. gen. Microbiol. 138 : 1837 1842, 1992.

19) Hoshino, T., Fujimura, S. and Nakamura, T. : Isolation and biological properties of oral spirochete, Treponema denticola. Matsumoto Shigaku 22:8〜12, 1996.

20) Potier, M., Mameli, L., Bélisle, M., Dallaire, L. and Melançon, S. B. : Fluorometric assay of neuraminidase with a sodium (4-methylumbelliferyl$\alpha-\mathrm{D}-\mathrm{N}$-acetylneuraminate) substrate. Anal. Biochem. $94: 287 \sim 296,1979$.

21) Bradford, M. M. : A rapid and sensitive method for the quantitation of microgram quantities of protein utilizing the principle of protein-dye binding. Anal. Biochem. 72 : 248 254, 1976.

22) Laemmli, U. K. : Cleavage of structural proteins during the assembly of the head of bacteriophage T4. Nature (London), $227: 680 \sim 685,1970$.

23) Kitawaki M., Iijima K., Nakashizuka T. and Hayakawa, T.: Neuraminidase activity in human crevicular fluid. J. periodont. Res. $18: 318$ $\sim 320,1983$.

24) Beighton, D., Radford, J. R. and Naylor, M. N. : Glycosidase activities in gingival crevicular fluid in subjects with adult periodontitis or gingivitis. Archs. oral Biol. 37 : 343 348, 1992. 